\title{
Variable phytoplankton response to enhanced UV-B and nitrate addition in mesocosm experiments at three latitudes (Canada, Brazil and Argentina)
}

\author{
Maria Lorena Longhi ${ }^{1,4}$, Gustavo Ferreyra ${ }^{1,2}$, Irene Schloss ${ }^{2,3}$, Suzanne Roy ${ }^{1, *}$ \\ ${ }^{1}$ Institut des Sciences de la Mer de Rimouski, Université du Québec à Rimouski, 310 Allée des Ursulines, Rimouski, \\ Québec G5L 3A1, Canada \\ ${ }^{2}$ Instituto Antártico Argentino, Cerrito 1248, C1010AAZ, Buenos Aires, Argentina \\ ${ }^{3}$ Consejo Nacional de Investigaciones Científicas y Técnicas (CONICET), Argentina \\ ${ }^{4}$ Present address: Faculté des Sciences, Université du Québec à Montréal, succ. Centre-Ville, C.P. 8888, \\ Montréal, Québec H3C 3P8, Canada
}

\begin{abstract}
The influence of nitrate enrichment on the response of natural phytoplankton populations to enhanced UV-B radiation was tested during a series of week-long mesocosm (1800 l) experiments carried out in Rimouski (Canada), Ubatuba (Brazil) and Ushuaia (southern Argentina). We set up 2 mesocosms at each site, one was submitted to ambient UV-B levels while the other received enhanced UV-B levels corresponding to a local $60 \%$ ozone-depletion scenario, and both were continuously mixed. Samples from the mesocosms were incubated in UV-transparent plastic bags (4 l) floating at the surface for $24 \mathrm{~h}$. Half of these received nitrate, phosphate and silicate enrichments while for the other half nitrate was omitted. Responses in terms of photochemical yield $\left(F_{\mathrm{v}} / F_{\mathrm{m}}\right.$, where $F_{\mathrm{v}}$ is variable fluorescence after dark relaxation and $F_{\mathrm{m}}$ is maximal fluorescence following short pulses of saturating white light, pulse amplitude-modulated [PAM] fluorescence) and high-performance liquid chromatography (HPLC) pigments, differed among sites and over time, particularly for Rimouski, where a large bloom took place in the mesocosms. Enhanced UV-B significantly increased photoinhibition in the surface bags, while nitrate addition partly relieved this inhibition only during the post-bloom period. The net growth of fucoxanthin was reduced by enhanced UV-B except during the post-bloom period, when it increased, probably because grazing pressure was reduced under enhanced UV-B (strong decrease in ciliates). In Ubatuba, cells were affected by the high ambient-light irradiances at the surface, and enhanced UV-B had no further effect, irrespective of the nutrient status. At Ushuaia, enhanced UV-B prevented all increases of fucoxanthin and chl $a$, with much less effect on chl $b$ (green algae), and no nutrient response was observed. This strong and consistent negative response to enhanced UV-B is likely to be related to the cold temperature prevailing at Ushuaia at the time of the experiment (slowing repair) as well as the local community composition. In contrast, no effects of enhanced UV-B were observed in the stirred mesocosms at the 3 sites, indicating that mixing moderated the UV-B effects in all 3 experiments.
\end{abstract}

KEY WORDS: UV-B radiation $\cdot$ Nutrient status $\cdot$ Phytoplankton $\cdot F_{\mathrm{v}} / F_{\mathrm{m}} \cdot$ Pigments $\cdot$ Latitudinal variations $\cdot$ Nitrate availability

Resale or republication not permitted without written consent of the publisher-

\section{INTRODUCTION}

It is now clearly established that the ozone-related increase in ultraviolet-B radiation (UV-B, 280 to $320 \mathrm{~nm}$ ) may harm phytoplankton (Vincent \& Roy 1993, Vincent \& Neale 2000, Buma et al. 2003). However, assessing phytoplankton response to UV-B in nature is com- plex for several reasons, including species-specific sensitivity, movement in the water column and light history of phytoplankton assemblages (Villafañe et al. 2004), as well as the influence of co-occurring stresses (Litchman et al. 2002).

While incident solar radiation is generally highest in the tropics, there is a more pronounced seasonal in- 
crease in ozone-induced UV-B flux from mid- to highlatitudes (Tarasick et al. 2003). It has been suggested that tropical species are less sensitive to enhanced UV-B, because they have an evolutionary history of exposure to high and more constant PAR (photosynthetically available radiation, 400 to $700 \mathrm{~nm}$ ), UV-A (320 to $400 \mathrm{~nm}$ ) and UV-B flux that permits the development of adaptation processes (Hazzard et al. 1997, Helbling et al. 1992, 2003). In addition, the high temperatures of tropical regions favor fast repair of UV-B damage (Roos \& Vincent 1998, Critchley 2000).

Combined UV-B and nutrient stress play an undetermined role in phytoplankton. Several studies have revealed that phytoplankton were more affected by enhanced UV-B radiation under nutrient-limited conditions (Cullen \& Lesser 1991, Bergeron \& Vincent 1997, Wulff et al. 2000, Litchman et al. 2002). Nutrient stress may increase the sensitivity to UV-B through the alteration of several mechanisms of protection, defence against UV-B radiation or repair after photodamage (Lesser 1996, Bergmann et al. 2002, Litchman et al. 2002). In contrast, other studies found little or no increase of UV-B sensitivity in nutrient-stressed phytoplankton (Behrenfeld et al. 1994, Furgal \& Smith 1997, Veen et al. 1997, Wängberg et al. 1999). Part of this discrepancy may be related to the time scale of the experiments, whereby short-term studies amplify the effect of enhanced UV-B because they are not long enough to allow repair or acclimation (Vernet 2000).

Consequently, in the present study we compared the phytoplankton response to enhanced UV-B with or without nitrate addition in 3 environments, but after a $24 \mathrm{~h}$ period in situ to allow repair or acclimation to take place. This time period should be sufficient to allow significant growth recovery from nutrient deficiency, if any (Brussaard et al. 1998). The 3 environments comprised a northern mesotrophic site (Canada), a tropical meso-oligotrophic site (Brazil) and a southern mesotrophic site occasionally exposed to the Antarctic ozone-hole (southern Argentina). These probably support communities that differ in terms of light-adaptation characteristics. All environments were submitted to an enhanced UV-B treatment representative of a $60 \%$ ozone-depletion scenario appropriate for the latitude of the chosen sites. This scenario reflects common ozone depletions observed in Antarctica (cf. (http://www.jwocky.gsfc.nasa.gov) NASA's total ozone mapping spectrometry [TOMS] data).

\section{MATERIALS AND METHODS}

Mesocosm experimental set-up. Mesocosm experiments were performed at Rimouski, Canada $\left(48.4^{\circ} \mathrm{N}\right.$, $68.53^{\circ} \mathrm{W}$ ) from 18 to 27 June 2000, at Ubatuba, Brazil $\left(23.5^{\circ} \mathrm{S}, 45.07^{\circ} \mathrm{W}\right)$ between 10 and 16 February 2001, and at Ushuaia, Argentina $\left(54.8^{\circ} \mathrm{S}, 68.2^{\circ} \mathrm{W}\right)$ between 6 and 15 November 2001. The experiments involved 2 floating mesocosms ( 1800 l, $1.2 \mathrm{~m}$ diameter and 2.3, 1.9 and $2.4 \mathrm{~m}$ deep at Rimouski, Ubatuba and Ushuaia, respectively) tied to a wharf. The mesocosms were made of UV-transparent polyethylene bags (light transmission $=85 \%$ in the UV range and $93 \%$ in the 400 to $750 \mathrm{~nm}$ range). They were all filled simultaneously $1 \mathrm{~d}$ before starting the experiments (Day 0) with $500 \mu \mathrm{m}$-filtered coastal seawater from near-surface $(2$ to $5 \mathrm{~m}$ ) waters. In Ushuaia, nutrients (a 21 solution containing $2 \mu \mathrm{M}$ of $\mathrm{NO}_{3}{ }^{-}$and $3.3 \mu \mathrm{M}$ of $\left.\mathrm{Si}(\mathrm{OH})_{4}\right)$ were added to the collected seawater prior to filling the mesocosms, because the initial nutrient levels were too low to sustain a $10 \mathrm{~d}$ experiment (the low nutrients were due to the timing of the experiment, soon after the local spring bloom, but local waters are not oligotrophic in general, hence the decision to add nutrients in this case). The water in each mesocosm was continuously mixed with Little Giant ${ }^{\circledR}$ pumps (Model 2MD-MC) with an estimated complete turnover time of $1.3 \mathrm{~h}$, maintaining a homogeneous water column and preventing cells from settling. Clear polyethylene sheets were placed over each mesocosm during the night, as well as when it rained. Surface-water temperature in the mesocosms was continuously measured with thermocouples (Type ' $J$ ') connected to a datalogger (Model 21X, Campbell Scientific). Salinity was determined from daily subsamples taken at the surface of the mesocosms using local salinometers or CTD instruments.

The 2 mesocosms were each exposed to a different UV-B treatment, either ambient UV-B (NUV-B) or enhanced UV-B conditions (HUV-B). The enhanced UVB simulated a $60 \%$ ozone-depletion scenario from the average 1979 to 1982 TOMS ozone columns at the respective sites (Díaz et al. 2003), using 4 preburned (>100 h) UV-B fluorescent light tubes (Philips TL 40W12RS, emission peak at $313 \mathrm{~nm}$, Díaz et al. 2003) suspended 30 to $40 \mathrm{~cm}$ above the water surface of the mesocosm. These ozone values were introduced as inputs in a model constructed by Díaz et al. (2002) to determine the climatological irradiances: namely, because of differences in the solar zenith angle, a similar ozone depletion will produce different relative increases in UV-B irradiances for different geographical locations and times of the year. This was taken into account by the model and explains the differences in relative increases between the NUV-B and HUV-B treatments for the 3 sites. During the Rimouski experiment, the lamps were turned on from 10:00 to 15:00 h for the $10 \mathrm{~d}$ of the experiment, while in Ushuaia they were on from 11:00 to 16:00 h from Days 3 to 10 (to allow some growth before the experiment began). In 
Ubatuba, the UV-B lamps were adjusted by a computer-controlled system with an electronic unit linked to UV-B detectors set in the NUV-B and HUV-B mesocosms. This system provided a constant proportional enhancement of UV-B, following the daily ambient variations (Díaz et al. 2003). It unfortunately malfunctioned in Rimouski and Ushuaia (partly due to cold temperatures in Ushuaia which affected the lamps' electronic ballasts). For all sites, the lamps were covered with cellulose diacetate sheets $(0.13 \mathrm{~mm}$; changed daily) to filter-out the UV-C radiation emitted by the lamps. To simulate shading caused by the lamp set-up over the HUV-B mesocosm, wooden dummies were suspended at the same height over the NUV-B mesocosm.

Irradiance measurements. In Rimouski and Ubatuba, incident irradiance was recorded on the wharf using a surface radiometer (GUV510) at 5 wavelengths (305, $313,320,340$ and $380 \mathrm{~nm}$ ) as well as PAR; these readings also served to correct for cloud interference during the vertical profiles. In Ubatuba, an IL1700 (International Light) radiometer with SUD033/PAR/W (PAR: photosynthetic active radiation, 400 to $700 \mathrm{~nm}$ ), SUD033/UVA/W (UV-A) and SUD240/SPS300/T/W (UV-B) sensors was used to adjust the variable UV-B lamp output. In Ushuaia, we used a Ground-based Ultraviolet Radiometer (GUV-510; Biospherical instruments) installed on the roof of CADIC (Centro Austral de Investigaciones Científicas, Argentina), $5 \mathrm{~km}$ from the site of the experiment. Daily fluence just below the water surface for each bioassay was obtained by time integration of incident irradiances over each day, corrected for the shading due to the lamp fixtures. Vertical profiles of UV and PAR irradiance in each mesocosm were obtained with a Profiling Ultraviolet Radiometer (PUV-500; Biospherical Instruments) recording at the same wavelengths as the GUV. The vertical attenuation coefficient $\left(k_{\mathrm{d}}, \mathrm{m}^{-1}\right)$ was calculated from the slope of $\ln$ (irradiance) with depth, and the mean depth of $1 \%$ light penetration was determined as $\ln (0.01) k_{\mathrm{d}}{ }^{-1}$.

Experimental design. To test for the combined effect of UV-B and nutrient status, water from each of the 2 mesocosms was enclosed in $41 \mathrm{UV}$-transparent Ziploctype bags (transmission $=86$ to $94 \%$ in the 280 to $750 \mathrm{~nm}$ range) and exposed at the surface of the mesocosms. We applied 2 treatments - UV-B and nutrients, each with 2 levels: (1) exposure to natural UV-B irradiance (in the NUV-B mesocosm) and (2) exposure to enhanced UV-B irradiance (in the HUV-B mesocosm), with 2 nutrient conditions for each: (1) all macronutrients added (All, nitrate, phosphate and silicic acid), and (2) all macronutrients added except nitrate (All $-\mathrm{N}$ ). We filled 6 bags per mesocosm ( 3 for each nutrient treatment), and these were incubated floating just below the water surface of the respective mesocosms for $24 \mathrm{~h}$ (generally starting at 18:00 h). The concentration of the nutrient enrichments was chosen on the basis of the local ambient nutrient concentrations below the surface layer of each site, mimicking a mixing event with deeper waters. These additions were $15 \mu \mathrm{M} \mathrm{NO}_{3}{ }^{-}, 1 \mu \mathrm{M} \mathrm{PO}_{4}{ }^{3-}$ and $15 \mu \mathrm{M} \mathrm{Si}(\mathrm{OH})_{4}$ for the Rimouski experiment; $2 \mu \mathrm{M} \mathrm{NO}_{3}{ }^{-}, 0.3 \mu \mathrm{M} \mathrm{PO}_{4}{ }^{3-}$ and $2 \mu \mathrm{M} \mathrm{Si}(\mathrm{OH})_{4}$ for Ubatuba; and $5 \mu \mathrm{M} \mathrm{NO}_{3}{ }^{-}, 2 \mu \mathrm{M}$ $\mathrm{PO}_{4}{ }^{3-}$ and $5 \mu \mathrm{M} \mathrm{Si}(\mathrm{OH})_{4}$ for Ushuaia. We performed 2 or 3 such $24 \mathrm{~h}$ bioassays during each mesocosm experiment at each site, corresponding with the different phases of phytoplankton development and thus corresponding to different nutrient levels in the mesocosms. Variables from the small-bag incubations were measured at the initial and final time ( $t_{\mathrm{i}}$ and $t_{\mathrm{f}}$ respectively) of each $24 \mathrm{~h}$ bioassay.

Measured variables. Nutrients: Subsamples for nutrient analysis from the mesocosms and the small bags were filtered through precombusted Whatman GF/F filters, and the filtrate was collected after passage of at least $10 \mathrm{ml}$ through the filters. In Rimouski and Ushuaia, the filtrate was frozen at $-80^{\circ} \mathrm{C}$ in acid-cleaned polypropylene cryogenic vials for the local determination of ambient $\mathrm{NO}_{3}{ }^{-}+\mathrm{NO}_{2}{ }^{-}, \mathrm{NO}_{2}{ }^{-}, \mathrm{PO}_{4}{ }^{3-}$ and $\mathrm{Si}(\mathrm{OH})_{4}$ using a Technicon II Autoanalyzer (Strickland \& Parsons 1972). In Ubatuba, determinations of ambient $\mathrm{NO}_{3}{ }^{-}+\mathrm{NO}_{2}{ }^{-}$and $\mathrm{NO}_{2}{ }^{-}$were made locally with a BranLuebbe Autoanalyzer II, and $\mathrm{PO}_{4}{ }^{3-}$ and $\mathrm{Si}(\mathrm{OH})_{4}$ were analyzed following the method of Grasshoff et al. (1983).

Particulate organic carbon and nitrogen: Subsamples for the determination of particulate organic carbon and nitrogen (POC and PON, respectively) were collected on precombusted Whatman GF/F filters stored at $-20^{\circ} \mathrm{C}$ before being analyzed with a PerkinElmer CHN analyzer (Model 2400). Samples from Ubatuba and Ushuaia were frozen in liquid nitrogen, shipped to Rimouski in a dry-shipper, and stored at $-20^{\circ} \mathrm{C}$ until analysis.

Taxon-marker and photoprotective pigments. Daily subsamples from mesocosms (1 l l) and subsamples from each small Ziploc-type bag (300 to $500 \mathrm{ml}$ ) were filtered onto Whatman GF/F filters and immediately frozen in liquid nitrogen. Samples from Ubatuba and Ushuaia were shipped frozen to Rimouski using a dry-shipper. All samples were stored at $-80^{\circ}$ before analysis using high-performance liquid chromatography (HPLC) according to Wright et al. (1991) as modified by Roy et al. (1996) for the Rimouski samples, and using the method of Zapata et al. (2000) for the samples from Ubatuba and Ushuaia. The rate of change $\left(\mathrm{d}^{-1}\right)$ or net community growth rate of chl $a$ and taxon-marker pigments in the surface bags and in the mesocosms from each site was assessed from changes over $24 \mathrm{~h}$ using the equation

$$
\text { Rate of change }=\ln \left(C_{\mathrm{f}} / C_{\mathrm{i}}\right) /\left(t_{\mathrm{f}}-t_{\mathrm{i}}\right)
$$


where $C_{\mathrm{f}}$ and $C_{\mathrm{i}}$ are the pigment concentration at final and initial times ( $t_{\mathrm{f}}$ and $t_{\mathrm{i}}$, respectively).

Fluorescence: Photosynthetic performance was assessed using fluorescence kinetics, measured following the multiple turnover method with a Xe-PAM (xenon pulse amplitude-modulated fluorometer from Walz: cf. Schreiber et al. 1993). The maximum quantum yield of the open Photosystem II (PSII) reaction centres (nomenclature according to Maxwell \& Johnson 2000) was calculated with the following equation, $F_{\mathrm{v}} / F_{\mathrm{m}}=\left(F_{\mathrm{m}}-F_{0}\right) / F_{\mathrm{m}}$, where $F_{\mathrm{v}}$ is the variable fluorescence after dark relaxation (at least 45 min: Büchel \& Wilhelm 1993), measured from the difference between $F_{\mathrm{m}}$ and $F_{0}\left(F_{0}=\right.$ minimal fluorescence and $F_{\mathrm{m}}=$ maximal fluorescence following the application of short pulses of saturating white light $(600 \mathrm{~ms}, \sim 4000 \mu \mathrm{mol}$ photons $\mathrm{m}^{-2} \mathrm{~s}^{-1}$ ).

Statistical analysis. Significant effects of UV-B treatments (NUV-B and HUV-B) and nitrate conditions (with and without nitrate addition) were tested by repeated-measures analysis of variance (ANOVA), where the repeated measures were the successive incubations at each site. Normality was checked using the Kolmogorov-Smirnov test and the circularity assumption was checked using the Huynh-Feldt statistic (Scheiner \& Gurevitch 1993). Also, 1-way ANOVAs were used to test differences between nitrate condi- tions for each bioassay and for each UV-B treatment. The significance threshold was set at $\mathrm{p}<0.05$.

\section{RESULTS}

\section{Mesocosms at the 3 sites}

Maximal incident PAR and UV-B (305 nm) irradiances were highest at Ubatuba $(\sim 2400 \mu \mathrm{mol}$ photons $\mathrm{m}^{-2} \mathrm{~s}^{-1}$ and $\sim 9 \mu \mathrm{W} \mathrm{cm}{ }^{-2} \mathrm{~nm}^{-1}$ respectively; Fig. 1) and lowest at Ushuaia (generally $<2000 \mu \mathrm{mol}$ photons $\mathrm{m}^{-2}$ $\mathrm{s}^{-1}$, and $3 \mu \mathrm{W} \mathrm{cm}{ }^{-2} \mathrm{~nm}^{-1}$, respectively). Irradiances just below the water surface in the mesocosms were $\sim 70 \%$ of incident irradiances due to shading caused by the lamp fixtures. The daily fluence at the mesocosms' surface and averaged over the water column of the mesocosms was highest on Day 2 (first bioassay) and lowest on Day 10 (third bioassay) at Rimouski, and remained approximately the same for the various dates of the bioassays at each of the other 2 sites (Table 1 ). The mean $k_{\mathrm{d}}$ values and corresponding depths of $1 \%$ light penetration for PAR, UV-A (340 nm) and UV-B (305 nm) show that at Rimouski, PAR penetrated to the bottom of the mesocosms, UV-A reached only half of the mesocosm depth, and UV-B only one-third (Table 1), while at Ubatuba and Ushuaia, PAR, UV-A and UV-B reached
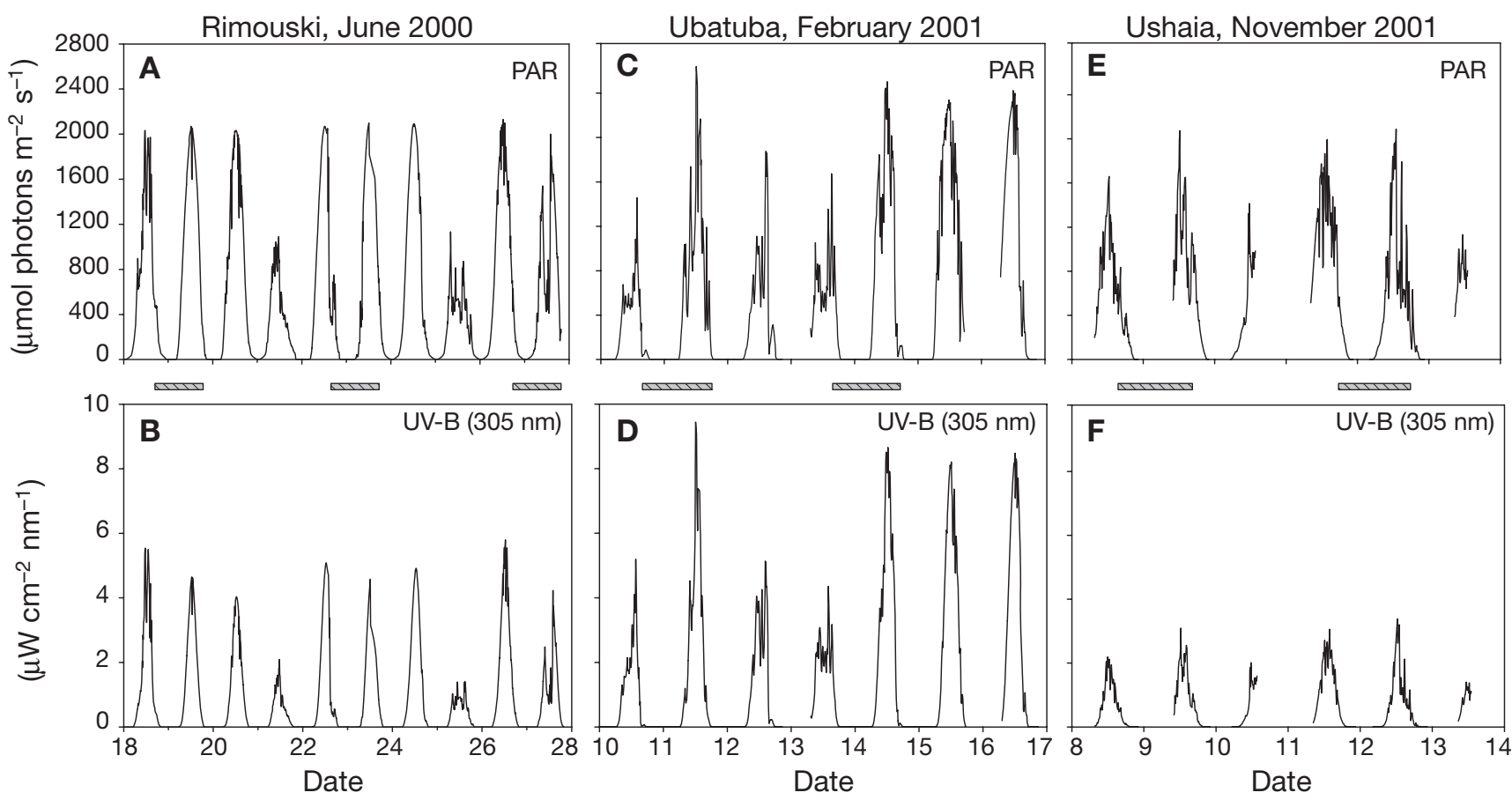

Fig. 1. Temporal variations in incident photosynthetically available radiation (PAR, 400 to $700 \mathrm{~nm}$ ) irradiance and UV-B (305 $\mathrm{nm}$ ) radiation at (A, B) Rimouski from Day 1 (18 June 2000) to Day 10 (27 June 2000), (C, D) Ubatuba from Day 1 (10 February 2001) to Day 7 (16 February 2001) and (E, F) Ushuaia from Day 3 (8 November 2001) to Day 8 (13 November 2001). All data smoothed by 10 min averages. Bars below PAR graphs: times of surface bioassays 
Table 1. Photosynthetically active radiation (PAR, mol photons $\mathrm{m}^{-2}$ ), and UV-A and UV-B $\left(\mathrm{kJ} \mathrm{m}^{-2} \mathrm{~nm}^{-1}\right)$ conditions at the 3 sites on dates of $24 \mathrm{~h}$ surface incubations. No light data were available for third bioassay (Days 9 and 10) in Ushuaia. Daily fluence at surface was corrected for lamp-shading effect. Daily fluence averaged over water column was calculated from Riley (1957) and equals daily surface irradiance $\times\left(1-\mathrm{e}^{-k_{\mathrm{d}} \cdot z}\right) \times\left(k_{\mathrm{d}} z\right)^{-1}$, where $z$ is depth of the mesocosms. NUV-B, HUV-B: ambient and enhanced UV-B conditions, respectively

\begin{tabular}{|c|c|c|c|c|c|c|c|}
\hline \multirow{2}{*}{ Variable } & \multicolumn{3}{|c|}{ Rimouski } & \multicolumn{2}{|c|}{ Ubatuba } & \multicolumn{2}{|c|}{ Ushuaia } \\
\hline & $\begin{array}{l}19 \text { Jun } \\
\text { (Day 2) }\end{array}$ & $\begin{array}{l}23 \text { Jun } \\
\text { (Day 6) }\end{array}$ & $\begin{array}{l}27 \text { Jun } \\
\text { (Day 10) }\end{array}$ & $\begin{array}{l}11 \text { Feb } \\
\text { (Day 2) }\end{array}$ & $\begin{array}{c}14 \text { Feb } \\
\text { (Day 5) }\end{array}$ & $\begin{array}{c}9 \text { Nov } \\
\text { (Day 4) }\end{array}$ & $\begin{array}{l}12 \mathrm{Nov} \\
\text { (Day 7) }\end{array}$ \\
\hline \multicolumn{8}{|c|}{ Daily fluence at surface } \\
\hline PAR & 41.6 & 38.7 & 29.8 & 24.7 & 29.8 & 22.9 & 21.5 \\
\hline UV-A (340 nm) & 7.9 & 7.6 & 5.7 & 7.8 & 8.9 & 5.8 & 5.6 \\
\hline NUV-B (305 nm) & 0.4 & 0.4 & 0.3 & 0.8 & 0.9 & 0.3 & 0.3 \\
\hline HUV-B (305 nm) & 5.7 & 5.7 & 2.8 & 1.6 & 1.8 & 2.4 & 2.5 \\
\hline \multicolumn{8}{|c|}{ Daily fluence averaged over the water column } \\
\hline PAR & 19.0 & 14.1 & 10.1 & 15.9 & 15.3 & 12.1 & 12.5 \\
\hline UV-A (340 nm) & 1.0 & 1.0 & 0.7 & 2.4 & 2.7 & 1.7 & 1.7 \\
\hline NUV-B (305 nm) & 0.04 & 0.03 & 0.02 & 0.17 & 0.19 & 0.06 & 0.06 \\
\hline HUV-B (305 nm) & 0.53 & 0.43 & 0.18 & 0.30 & 0.36 & 0.40 & 0.39 \\
\hline \multicolumn{8}{|l|}{$k_{\mathrm{d}}\left(\mathrm{m}^{-1}\right)$} \\
\hline PAR & 0.8 & 1.1 & 1.2 & 0.5 & 0.8 & 0.6 & 0.5 \\
\hline UV-A (340 nm) & 3.3 & 3.3 & 3.8 & 1.6 & 1.7 & 1.4 & 1.3 \\
\hline UV-B (305 nm) & 4.4 & 5.4 & 5.9 & 2.5 & 2.6 & 1.9 & 1.8 \\
\hline \multicolumn{8}{|l|}{$Z_{\%}(\mathrm{~m})$} \\
\hline PAR & 5.8 & 4.2 & 3.8 & 9.2 & 5.8 & 7.7 & 9.2 \\
\hline UV-A (340 nm) & 1.4 & 1.4 & 1.2 & 2.9 & 2.7 & 3.3 & 3.5 \\
\hline UV-B (305 nm) & 1.1 & 0.9 & 0.8 & 1.8 & 1.8 & 2.4 & 2.6 \\
\hline
\end{tabular}

the bottom (or almost). The lamp-induced unweighted increase in UV irradiance (calculated from the $5 \mathrm{UV}$ wavelengths of the PUV) in the HUV-B mesocosm relative to the NUV-B treatment for a sunny day at noon was 1.73, 1.02 and 1.72 times greater in Rimouski, Ubatuba and Ushuaia, respectively (Table 2). When weighted with several biological weighting functions for inhibition of photosynthesis, this relative increase reached maximum values of 3.92 for Rimouski, 1.25 for

Table 2. Relative irradiance increases provided by UV-B lamps (compared to ambient light), immediately below water surface at noon on sunny day. Spectral irradiances from PUV500 profiling radiometer were weighted with biological weighting functions (BWF) for inhibition of photosynthesis for average mixture of diatoms and dinoflagellates (Neale \& Kieber 2000), for 2 green algae (a chlorophyte and a eustigmatophyte: Sobrino et al. 2005), and for a diatom (Cullen et al. 1992). For Rimouski, only BWF for mixture of diatoms and dinoflagellates was used, since phytoplankton was dominated by diatoms at this site

\begin{tabular}{|lccc|}
\hline Parameter & Rimouski & Ubatuba & Ushuaia \\
\hline Unweighted UV & 1.73 & 1.02 & 1.72 \\
$\begin{array}{l}\text { BWF for average mix of } \\
\text { diatoms and dinoflagellates }\end{array}$ & 3.92 & 1.25 & 4.16 \\
$\begin{array}{l}\text { BWF for green algae } \\
\text { BWF from Cullen et al. (1992) }\end{array}$ & 3.46 & 1.19 & 3.68 \\
\hline
\end{tabular}

Ubatuba and 4.16 for Ushuaia (Table 2). These values are slightly high, but in the same range as in some of the previous studies on mesocosms (see Mostajir et al. 1999). Mean water temperature at the surface of the mesocosms varied between 9.0 and $12.8^{\circ} \mathrm{C}$ at Rimouski, was constant at about $30^{\circ} \mathrm{C}$ at Ubatuba, and ranged between 6.2 and $8.6^{\circ} \mathrm{C}$ at Ushuaia. Salinity was 26, 34 and 32 at Rimouski, Ubatuba and Ushuaia, respectively. Ambient initial nitrate concentrations in the mesocosms were highest at Rimouski $(14.5 \mu \mathrm{M})$, intermediate at Ushuaia $(4.3 \mu \mathrm{M})$, and lowest at Ubatuba (1.5 to $2 \mu \mathrm{M})$ (Fig. 2A,C,E, respectively). For all 3 sites, these concentrations decreased rapidly, reaching close to undetectable levels on Day 7 at Rimouski, on Day 4 at Ubatuba and Day 6 at Ushuaia. A phytoplankton bloom developed in both NUV-B and HUV-B mesocosms at Rimouski and Ushuaia, reaching peak chl a concentrations near $25 \mu \mathrm{g} \mathrm{l}^{-1}$ on Day 7 at Rimouski and $8 \mu \mathrm{g} \mathrm{l}^{-1}$ on Day 6 at Ushuaia (Fig. 2B,F). No bloom was observed at Ubatuba: chl a concentrations gradually declined from their maximum value of about $5 \mu \mathrm{g} \mathrm{chl} \mathrm{a} \mathrm{l}^{-1}$ on Day 2 (Fig. 2D). For all 3 sites, there were few obvious differences between the trends for the NUV-B and HUV-B mesocosms.

\section{Rimouski bioassays}

During the first 2 bioassays, the POC:PON molar ratio was relatively low $(<10$, Fig. $3 A)$. At the start of the 

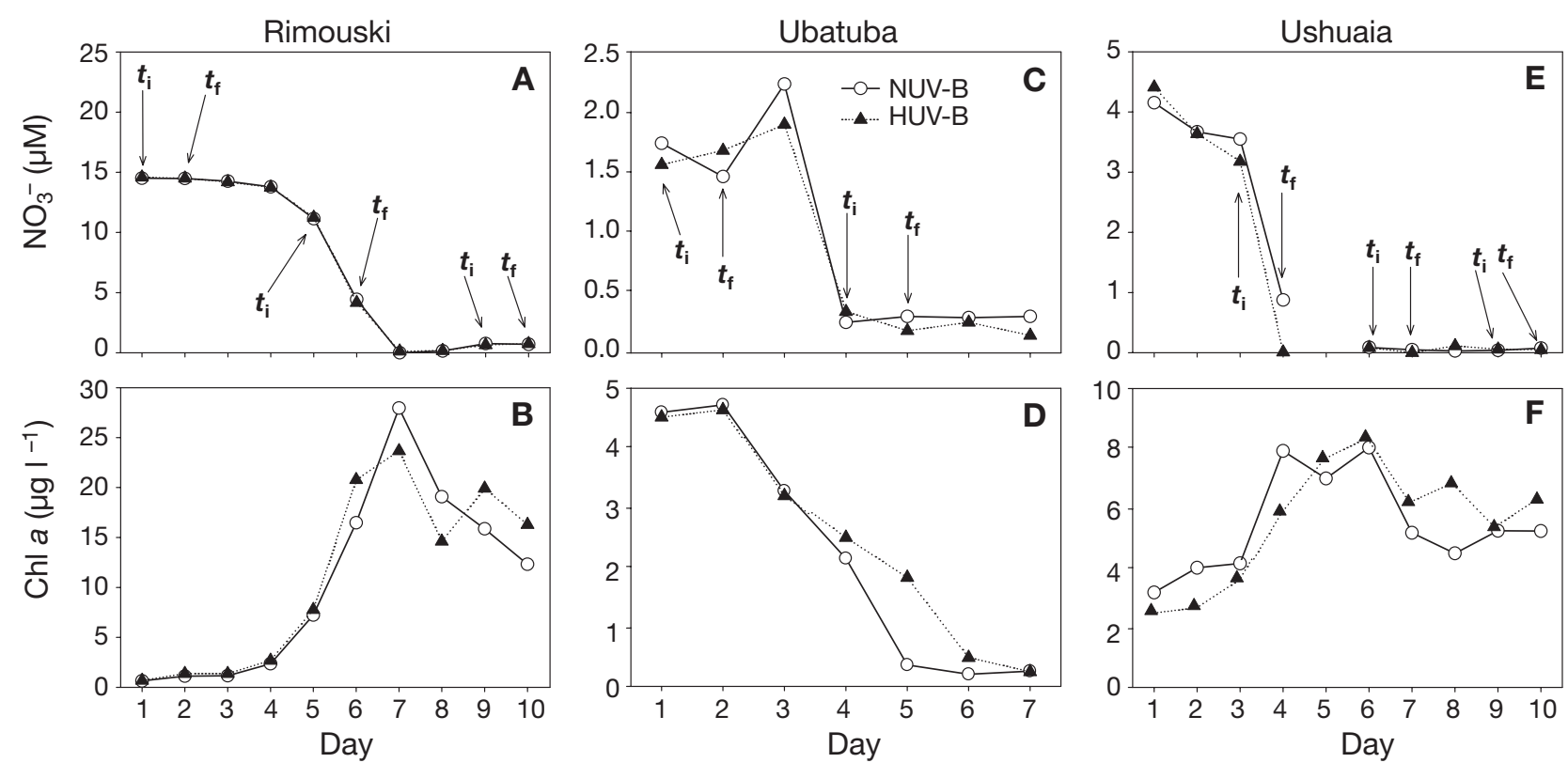

Fig. 2. Temporal variations in concentrations of nitrate and chlorophyll $a$ in mesocosms at the 3 sites under the 2 experimental treatments NUV-B and HUV-B radiation (i.e. ambient and enhanced UV-B, respectively). $t_{\mathrm{i}}$ and $t_{\mathrm{f}}$ : initial and final time of each bioassay, respectively

third bioassay (bloom-decline period), this ratio reached 20 , suggesting nitrogen-limiting conditions (nitrate had reached undetectable levels $2 \mathrm{~d}$ before). After $24 \mathrm{~h}$ of surface incubation, the POC:PON values increased in both All $-\mathrm{N}$ treatment bags, indicating further $\mathrm{N}$ deficiency, which was relieved with nitrate addition. No significant effect of the UV-B treatment on the POC:PON molar ratio was detected (Table 3).

\section{Chl $a$ and taxon-marker pigments}

The rate of change over $24 \mathrm{~h}$ of chl a and the 2 major marker pigments, fucoxanthin and chl $b$, was assessed in the mesocosms (from samples at 7:00 h on consecutive days) and in the bioassays (Figs. 4 \& 5). Whereas an increase in chl a was observed in the mesocosms (positive rate of change) during the first bioassay, a decrease took place in the surface bags at the same time (Figs. 4A \& 5A) suggesting that surface exposure induced chlorosis and/ or caused mortality of phytoplankton. During the bloom period (second bio-
Table 3. Repeated-measures ANOVA for variables measured in Rimouski, Ubatuba and Ushuaia experiments. POC: particulate organic matter; PON: particulate organic nitrogen; $F_{\mathrm{v}}$ : variable fluorescence after dark relaxation; $F_{\mathrm{m}}$ : maximal fluorescence following short pulses of saturating white light; Dd: diadinoxanthin; Dt: diatoxanthin; UV: UV-B radiation; Nut: nutrient; Bioass: bioassay; Source on variation partitioned into individual effects (UV, Nut), their interaction $(\mathrm{UV} \times \mathrm{Nut})$, the repeated measure (Bioass), and interaction between Bioass and individual effects. (Bioass $\times$ UV, Bioass $\times$ Nut, Bioass $\times \mathrm{UV} \times$ Nut). ${ }^{*} 0.01<\mathrm{p} \leq 0.05 ;{ }^{* *} 0.001<\mathrm{p} \leq 0.01 ;{ }^{* * *} \mathrm{p} \leq 0.001 ;$ ns: not significant

\begin{tabular}{|c|c|c|c|c|c|c|c|}
\hline & UV & Nut & $\begin{array}{l}\text { UV } \\
\times \text { Nut }\end{array}$ & Bioass & $\begin{array}{l}\text { Bioass } \\
\times \mathrm{UV}\end{array}$ & $\begin{array}{r}\text { Bioass } \\
\times \text { Nut }\end{array}$ & $\begin{array}{r}\text { Bioass } \times \\
\text { UV } \times \text { Nut }\end{array}$ \\
\hline \multicolumn{8}{|l|}{ Rimouski } \\
\hline Molar POC:PON & $\mathrm{ns}$ & $* * *$ & $\mathrm{~ns}$ & *** & $\mathrm{ns}$ & $* * *$ & $\mathrm{~ns}$ \\
\hline Chl a & ns & ns & ns & $* * *$ & ns & ns & ns \\
\hline Fucoxanthin & ns & ns & ns & $* * *$ & ${ }^{*}$ & ns & ns \\
\hline $\mathrm{Chl} b$ & ns & ns & ns & $* * *$ & ${ }^{*}$ & ns & ns \\
\hline$(\mathrm{Dd}+\mathrm{Dt}): \mathrm{chl} a$ & ${ }^{*}$ & ns & ns & $* * *$ & ns & ns & ns \\
\hline$F_{\mathrm{v}} / F_{\mathrm{m}}$ & * & $*$ & ns & $* * *$ & ns & ns & ns \\
\hline \multicolumn{8}{|l|}{ Ubatuba } \\
\hline Molar POC:PON & ns & ns & $\mathrm{ns}$ & $* * *$ & ns & $*$ & ns \\
\hline Chl a & $\mathrm{ns}$ & ns & ns & $*$ & ns & $\mathrm{ns}$ & ns \\
\hline Fucoxanthin & ns & ns & ns & $* * *$ & $*$ & ${ }^{*}$ & ns \\
\hline Zeaxanthin & $\mathrm{ns}$ & $\mathrm{ns}$ & $\mathrm{ns}$ & $*$ & $\mathrm{~ns}$ & $*$ & $\mathrm{~ns}$ \\
\hline$(\mathrm{Dd}+\mathrm{Dt}): \mathrm{chl} a$ & ns & ns & ns & ns & ns & ns & ns \\
\hline$F_{\mathrm{v}} / F_{\mathrm{m}}$ & ${ }^{*}$ & ns & ns & $* * *$ & ns & $* *$ & ns \\
\hline \multicolumn{8}{|l|}{ Ushuaia } \\
\hline Molar POC:PON & ns & $*$ & ns & $*$ & ns & ns & ns \\
\hline Chl a & $* *$ & ns & ns & ns & $*$ & ns & ns \\
\hline Fucoxanthin & $* * *$ & ns & ns & $*$ & ns & ns & ns \\
\hline $\mathrm{Chl} b$ & $\mathrm{~ns}$ & ns & ns & $*$ & ns & ns & ns \\
\hline$(\mathrm{Dd}+\mathrm{Dt}): \mathrm{chl} a$ & $* * *$ & ns & ns & $*$ & $*$ & ns & ns \\
\hline$F_{\mathrm{v}} / F_{\mathrm{m}}$ & $* * *$ & $\mathrm{~ns}$ & $\mathrm{~ns}$ & ns & $*$ & $\mathrm{~ns}$ & ns \\
\hline
\end{tabular}


assay), both NUV-B mesocosms and surface bags showed increases in $\mathrm{chl} a$, the rate of change being even higher in the surface bags $\left(\sim 1.2\right.$ vs. $\left.0.8 \mathrm{~d}^{-1}\right)$ indicating that surface conditions were not detrimental at that time. These net chl a increases are more likely to be the result of increased cell abundance than changes in the cell concentration of pigments, as chl a concentrations generally decrease under high irradiances (e.g. MacIntyre et al. 2002). Interestingly, the net growth of chl a was lower in the HUV-B surface bags $($ All $-\mathrm{N})$ than in the HUV-B mesocosm $\left(0.6\right.$ vs. $\left.\sim 1 \mathrm{~d}^{-1}\right)$. In the post-bloom period (third bioassay), chl a increased in the surface bags, while it decreased in the mesocosms. In this last bioassay, including nitrate in the nutrient enrichments slightly increased chl $a$ in both UV-B treatments, but this was not statistically significant (Table 3).

The major taxon-marker pigment detected at this site, fucoxanthin ( $60 \%$ of chl a biomass), indicated the presence of diatoms (confirmed with microscopy; dominant species $=$ Thalassiosira spp.). The repeatedmeasures ANOVA showed that the UV-B effect varied significantly among bioassays (Table 3). During the first bioassay, growth at the surface was positive for NUV-B (unlike chl a), but clearly reduced compared to growth in the mesocosms for both UV-B treatments. In fact, the HUV-B treatment completely suppressed any increase in fucoxanthin in the surface bags (Fig. 5B). In contrast, enhanced UV-B favored an increase in fucoxanthin in the mesocosms (Fig. 4B). During the second bioassay (at the peak of the bloom), fucoxanthin increased both in the mesocosms and in the surface bags (as did chl a) at roughly similar rates (slightly higher at the surface). However, the response to enhanced UV-B differed, with a decrease at the surface, but an increase in the HUV-B mesocosm. HUV-B thus affected fucoxanthin negatively only in the surface incubations. During the third bioassay (post-bloom), fucoxanthin decreased in both mesocosms while it increased in all surface bags, with rates similar to those observed in the second bioassay. Including nitrate in the enrichments during the post-bloom period significantly increased fucoxanthin in the surface bags for both UV-B treatments, while there was no clear effect of enhanced UV-B (Fig. 5B).

The other major marker pigment found at Rimouski was the green algae marker chl $b$ (representing $~ 30 \%$ of chl a biomass). In the mesocosms, chl $b$ showed an increase only in the HUV-B treatment during the first $2 \mathrm{~d}$ of the experiment (Fig. 4C). Green algae were probably displaced by the strong diatom bloom that followed. In the surface incubations, chl $b$ increased only for the NUV-B treatment during the first bioassay. Enhanced UV-B caused chl $b$ to decrease in the surface bags (Fig. 5C), suggesting a negative effect on green algae.
Photoprotective pigments

The chl a-specific pool size of xanthophyll cycle photoprotective pigments of chromophytes ([diadinoxanthin + diatoxanthin] $\times[\mathrm{chl} \mathrm{a}]^{-1}$ ) showed higher values after the $24 \mathrm{~h}$ surface bioassay in the bloom and postbloom periods in all treatments (Fig. 6A). In contrast, values remained constant in the mesocosms at the cor-
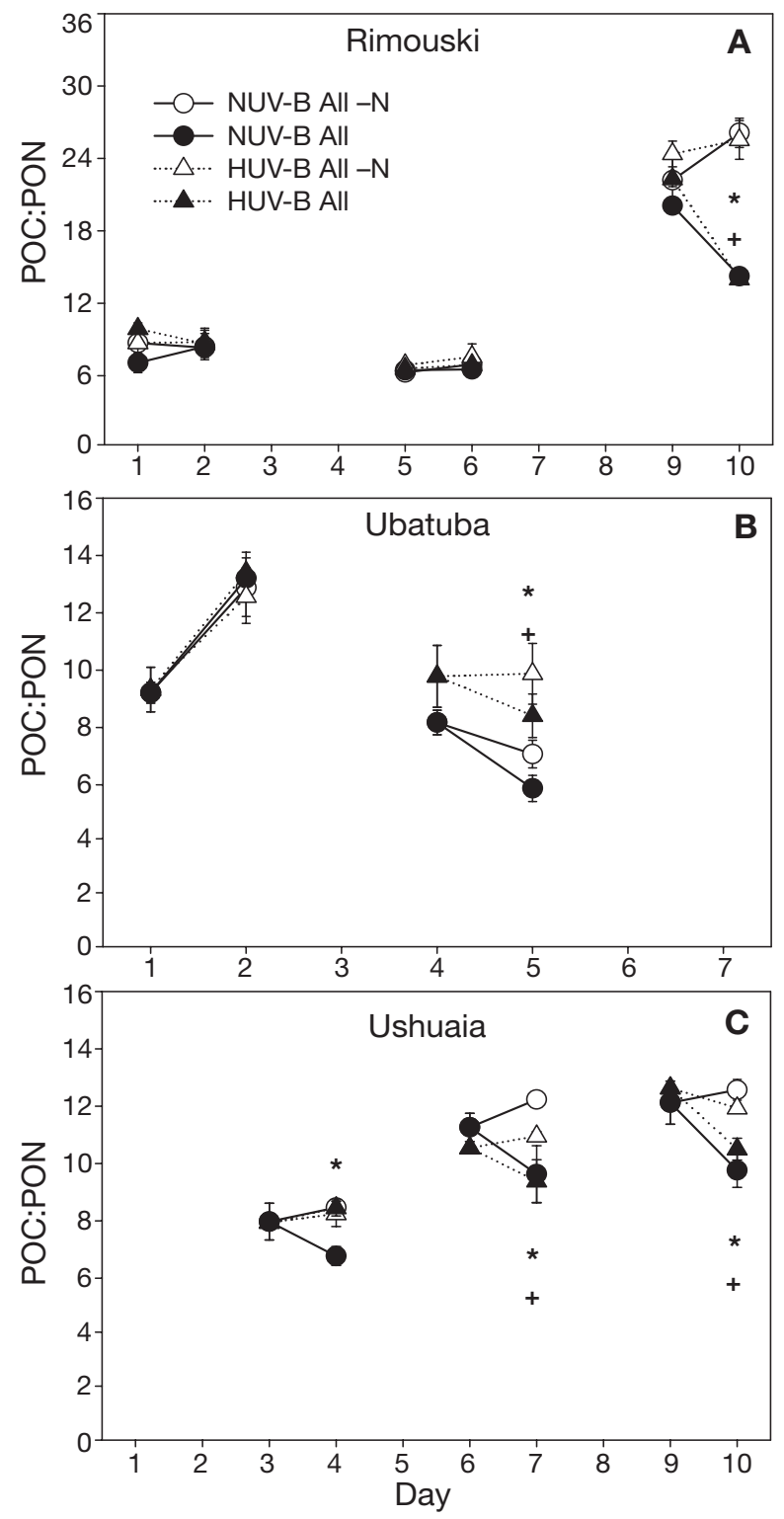

Fig. 3. POC:PON molar ratios at initial and final times for each bioassay at the 3 sites. Treatments were natural UV-B radiation with all macronutrients added except nitrate (NUV-B All $-\mathrm{N}$ ), with all macronutrients added (NUV-B All) and with enhanced UV-B radiation under the same 2 nutrient conditions (HUV-B All -N and HUV-B All, respectively). Data are averages \pm SD of 3 replicate bags. (*) Significant difference $(\mathrm{p}<0.05,1$-way ANOVA) between nutrient treatments under NUV-B radiation; $(+)$ significant difference $(\mathrm{p}<0.05,1$-way ANOVA) between nutrient treatments under HUV-B radiation 

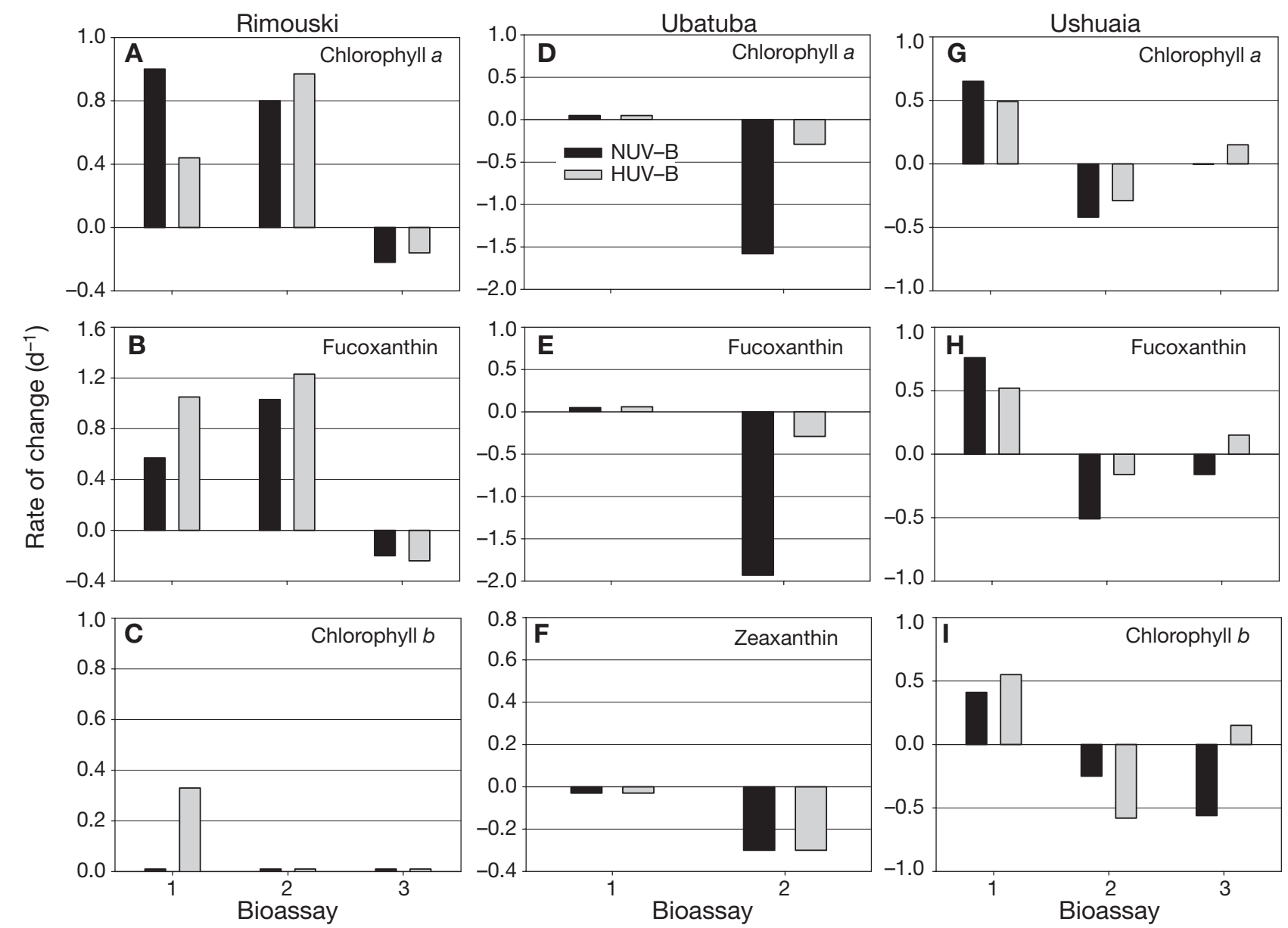

Fig. 4. Growth rate calculated for chlorophyll $a$ and $b$, and for taxon-marker pigments, in mesocosms for each bioassay at the 3 study sites. Treatments as in Fig. 2

responding times (not shown). The UV-B treatment had an overall significant effect on these pigments (Table 3), with higher concentrations in the HUV-B treatment. This was most evident in the second bioassay (during the bloom). Hence, both incubation at surface and enhanced UV-B treatment induced an increase in these photoprotective pigments.

\section{Fluorescence}

Cells were strongly photoinhibited after $24 \mathrm{~h}$ surface incubation during the bloom and post-bloom phases (shown by decreases in $F_{\mathrm{v}} / F_{\mathrm{m}}$, Fig. 6B). The decrease in $F_{\mathrm{v}} / F_{\mathrm{m}}$ was highest (nearly $50 \%$ ) during the bloom period. Enhanced UV-B significantly amplified the decrease in $F_{\mathrm{v}} / F_{\mathrm{m}}$ (increased photoinhibition) throughout the experiment (Table 3). The difference between NUV-B and HUV-B was small during the bloom (only about $10 \%$ more photoinhibition with enhanced UVB), but much higher during the post-bloom period, where the $F_{\mathrm{v}} / F_{\mathrm{m}}$ decrease rose from $27 \%$ (initial val- ues) in NUV-B to $50 \%$ in the HUV-B treatment. The nutrient treatment also showed an overall significant effect on $F_{\mathrm{v}} / F_{\mathrm{m}}$, that was clearest during the postbloom period, when the addition of nitrate significantly reduced the $F_{\mathrm{v}} / F_{\mathrm{m}}$ decrease in the enhanced UV-B treatment.

\section{Ubatuba bioassays}

During the first bioassay, the POC:PON molar ratio increased from $\sim 9$ to 13 after $24 \mathrm{~h}$ in all treatments, indicating progressive nutrient deficiency (Fig. 3B), but nitrate addition had no significant effect, possibly because the major $\mathrm{N}$ source was not nitrate. At the start of the second bioassay, the POC:PON ratio was $\sim 8$ to 10 and it remained constant or decreased slightly after $24 \mathrm{~h}$ (Fig. 3B) even though nitrate had by then reached close to undetectable levels (Fig. 2C). Heterotrophs, which are generally present in oligotrophic environments, may have influenced this ratio. The nutrient-treatment effect was significantly different between the 2 bioassays (Table 3). Only in the second 
bioassay was the POC:PON ratio significantly reduced (1-way ANOVA) under both UV-B treatments when nitrate was added, suggesting that nitrate was used only in the second bioassay.

\section{Chlorophyll $a$ and taxon-marker pigments}

Phytoplankton cells showed no increase in chl a in the mesocosms or the surface incubations in either bioassay (Figs. 4D \& 5D). In general, a more pronounced chl a decrease was observed in the surface bags than in the mesocosms, and this decrease was even more pronounced in the second bioassay. Furthermore, there were no significant UV-B or nutrient treatment effects on chl a overall (Table 3 ). The major taxonmarker pigment detected was fucoxanthin (Figs. 4E \& $5 \mathrm{E})$, which here was probably an indicator of the presence of both prymnesiophytes and diatoms (small $<5 \mu \mathrm{m}$ phytoflagellates dominated in the microscopy counts), followed by zeaxanthin, commonly found in cyanobacteria (Figs. 4F \& 5F) (mostly Johannesbaptista pellucida). Chlorophylls $c_{3}$ (mostly prymnesiophytes) and $b$ were also present. Fucoxanthin increased slightly only in the first bioassay when nitrate was present in the enriched bags (irrespective of the UV-B treatment). Fucoxanthin showed a slight increase in the mesocosms at this time. In both mesocosms and surface bags, fucoxanthin decreased strongly during the second bioassay, particularly under the enhanced UV-B treatment in the surface incubations (Fig. 5E). The repeated-measures ANOVA indicated that the effect of both nutrient and UV treatments on the rate of change of this pigment varied significantly with the bioassay, with a small but significant increase when nitrate was added only in the first bioassay. Hence, nitrate addition allowed some growth of fucoxanthin-containing cells (or increased their fucoxanthin content) during the first $2 \mathrm{~d}$ of the experiment at Ubatuba, but not later on. The response was slightly different for zeaxanthin. While it
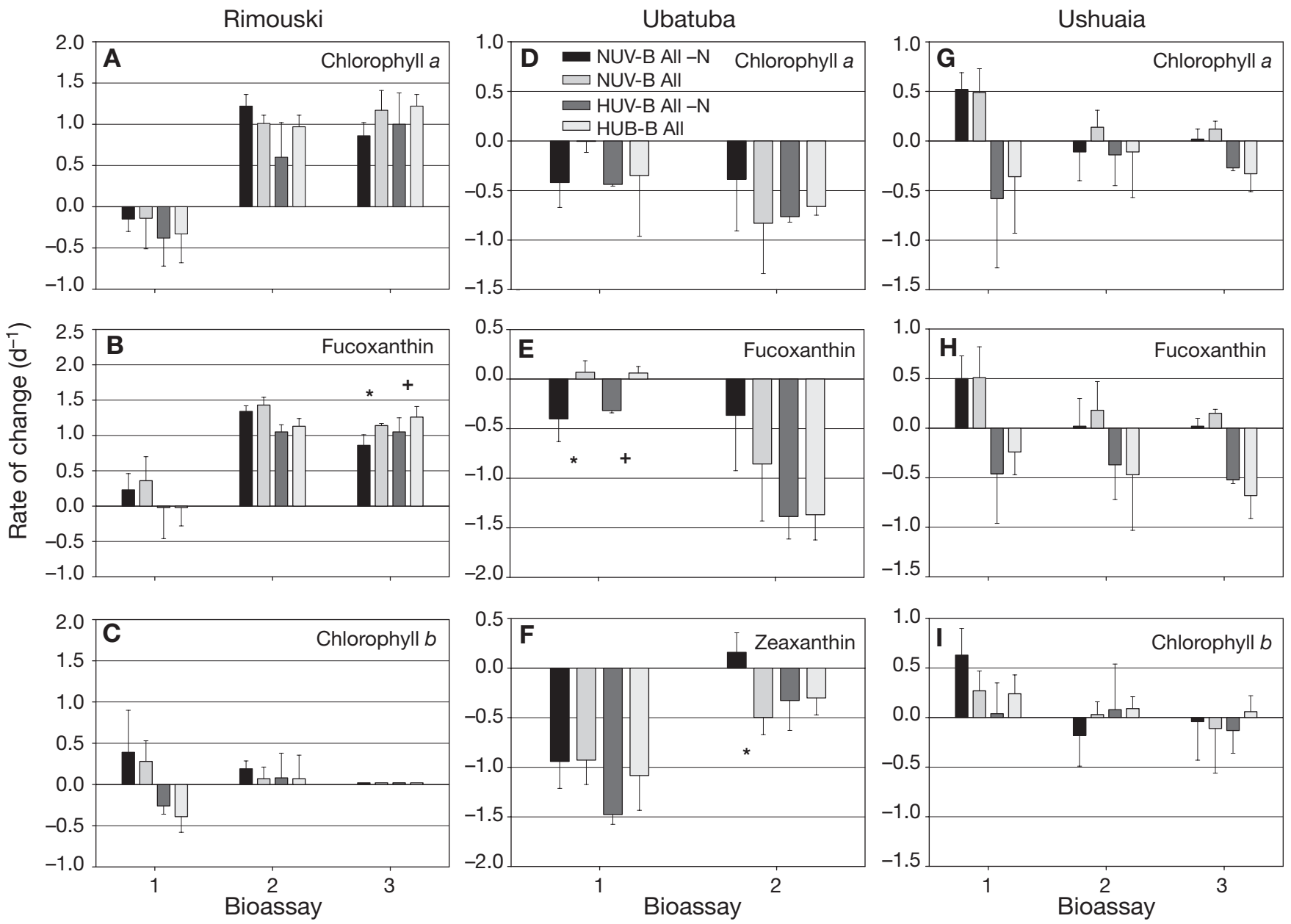

Fig. 5. Growth rate $( \pm \mathrm{SD})$ calculated for chlorophyll $a$ and $b$, and for taxon-marker pigments in each bio-assay (surface bags) at the 3 study sites. Treatments and symbols as in Fig. 3 

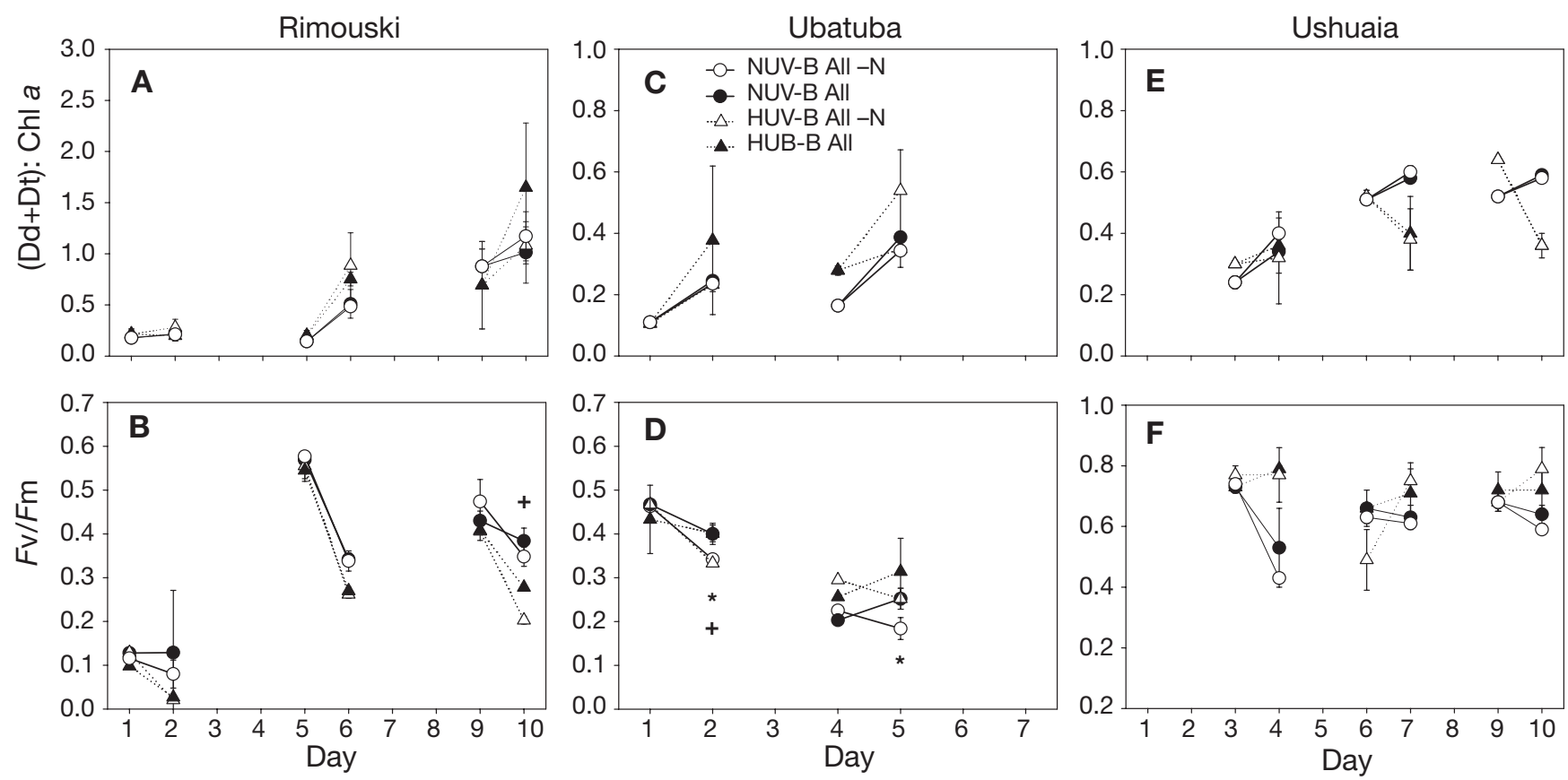

Fig. 6. Xanthophyll-cycle photoprotective pigments (expressed as chl-specific ratio (diadinoxanthin [Dd] + diatoxanthin [Dt]): $\left.(\mathrm{chl} \mathrm{a})^{-1}\right)$ and photochemical quantum yield $\left(F_{\mathrm{v}} / F_{\mathrm{m}}\right.$, where $F_{\mathrm{v}}$ is variable fluorescence after dark relaxation and $F_{\mathrm{m}}$ is maximal fluorescence following short pulses of saturating white light) at initial and final times of each bioassay at the 3 study sites.

Treatments and symbols as in Fig. 3

decreased more strongly in the surface bags in the first bioassay (Days 1 and 2) than in the second, the reverse was observed in the mesocosms, with a stronger decrease in the second bioassay. Zeaxanthin increased only during the second bioassay in the NUV-B surface bags without nitrate addition. This increase could have resulted both from a change in the relative abundance of zeaxanthin-containing cells (e.g. cyanobacteria) or from an increase in cell-specific photoprotection (Kana et al. 1988, MacIntyre et al. 2002). Addition of nitrate here caused a significant decrease in this pigment in the second bioassay, while there was no significant effect of nitrate in the first bioassay. In contrast with fucoxanthin or zeaxanthin, $\mathrm{chl} c_{3}$ was the only pigment that increased under ambient UV-B conditions in the surface incubations, but in the first bioassay only (data not shown due to space limitation). Enhanced UV-B had a clear detrimental effect at this time, while no net growth was observed under all conditions in the second bioassay, with stronger decreases under NUV-B than under HUV-B. Nitrate addition had no effect on $\operatorname{chl} c_{3}$.

\section{Photoprotective pigments}

In both bioassays, the chl a-specific pool of photoprotective pigments increased significantly (1-way ANOVA) after $24 \mathrm{~h}$ at the surface, and also increased throughout the experiment (Fig. 6C). In contrast, no significant differences were detected between the various treatments (Table 3), although there were generally more photoprotective pigments under enhanced UV-B. In the mesocosms, photoprotective pigments remained constant between Days 1 and 2, but showed an increase between Days 4 and 5 (similar for both NUV-B and HUV-B mesocosms) (data not shown). Hence there was a larger increase in photoprotective pigments in the surface $24 \mathrm{~h}$ incubations compared to the mesocosms in the first bioassay, but similar increases in the second.

\section{Fluorescence}

A slight decrease in $F_{\mathrm{v}} / F_{\mathrm{m}}$ was observed after the $24 \mathrm{~h}$ surface incubation in the first bioassay $\left(24 \% F_{\mathrm{v}} / F_{\mathrm{m}}\right.$ decrease in NUV-B, All -N, Fig. 6D). Nitrate addition significantly reduced the photoinhibitory decrease in $F_{\mathrm{v}} / F_{\mathrm{m}}$ under both UV-B treatments (Table 3; 1-way ANOVA). In the second bioassay, low $F_{\mathrm{v}} / F_{\mathrm{m}}$ values were observed for all treatments, suggesting debilitating conditions. Cells exposed to HUV-B irradiance showed a better photosynthetic performance (higher $F_{\mathrm{v}} / F_{\mathrm{m}}$ ) than cells from NUV-B. Here, nitrate addition caused an increase in $F_{\mathrm{v}} / F_{\mathrm{m}}$ in both UV-B treatments, but this was significant only for the NUV-B treatment. Nitrate addition thus im- 
proved the photosynthetic performance in both bioassays, and samples from the HUV-B treatment showed a slightly better photosynthetic performance than those from NUV-B on Days 4 and 5. The smaller chl $c_{3}$ decrease in HUV-B compared to NUV-B surface bags in the second bioassay (data not shown), suggests that chl $C_{3}$-containing prymnesiophytes contributed to this better performance at that time.

\section{Ushuaia bioassays}

The POC:PON molar ratio showed no signs of strong nutrient limitation at Ushuaia. It remained relatively low and constant ( 7 to 9) in the pre-bloom period and the initial value increased slightly in the other 2 bioassays (Fig. 3C). Addition of nitrate significantly reduced the POC:PON ratio overall (Table 3), indicating that nitrate was used by the organisms present; this was particularly evident for the last 2 bioassays. There were no overall significant effects of UV-B enhancement on the POC:PON ratio.

\section{Chl $a$ and taxon-marker pigments}

The most striking result at Ushuaia was that the enhanced UV-B treatment prevented all growth of chl a (negative rate of change) in all 3 bioassays while an increase was observed in most NUV-B surface incubations (Fig. 5G). This lack of growth under enhanced UV-B was however not observed in the mesocosms, where chl $a$ increases were observed in 2 of the 3 cases (Fig. 4G). There was a similar trend, in both mesocosms and surface bags, of highest increases in all pigments during the first NUV-B bioassay. Nitrate addition had no effect, but enhanced UV-B had a clear and significant detrimental effect (Table 3). The major pigment markers at Ushuaia were fucoxanthin ( $60 \%$ of $\mathrm{chl} a$ biomass), representing mostly diatoms (notably Pseudo-nitzschia sp.), and chl $b$ ( $30 \%$ of chl a biomass), representing green algae such as euglenophytes (mostly Eutreptiella sp.). Microscopic results also indicated the presence of cryptophytes (alloxanthin present) and small flagellates $(<3 \mu \mathrm{m})$ in this community. In the mesocosms, increases in fucoxanthin, chl $a$ and chl $b$ were only observed during the first bioassay (both UV-B treatments) and during the last bioassay (HUV-B, Fig. $4 \mathrm{G}, \mathrm{H} \& \mathrm{I}$ ). In the surface incubations, enhanced UV-B prevented the growth of fucoxanthin (as for chl a) but not of chl $b$ overall (Table 3 ). While fucoxanthin increased only in the surface bags exposed to natural UV$B$ radiation (Fig. 5H), chl $b$ increased also under enhanced UV-B, particularly when nitrate was added (Fig. 5I). No significant overall effect of the nutrient treatments was however detected for either pigments. Cryptophytes (alloxanthin, not shown) reacted similarly to fucoxanthin, while zeaxanthin showed the same tendencies as chl $b$. Hence, the enhanced UV-B conditions had more detrimental effects on chromophytes (fucoxanthin and alloxanthin) than on green algae (chl $b$ and zeaxanthin) causing an increase in the relative abundance of green algae after $24 \mathrm{~h}$ at the surface. Nitrate addition had no significant influence in Ushuaia.

Photoprotective pigments

The chl $a$-specific pool of photoprotective pigments increased under all treatments after $24 \mathrm{~h}$ surface exposure in the pre-bloom period, with a slightly lower increase under HUV-B (Fig. 6E). However, in the bloom and post-bloom periods, these pigments increased only under NUV-B conditions while they decreased under HUV-B conditions, reflecting the decrease of fucoxanthin-containing cells. Overall, the significant effect of the UV-B treatment over these photoprotective pigments differed as a function of bioassay, with clear decreases under HUV-B in the last 2 bioassays (Table 3 ).

\section{Fluorescence}

In all 3 bioassays, the maximum quantum yield decreased when cells were exposed for $24 \mathrm{~h}$ at the surface in the NUV-B treatment (most strongly during the first bioassay, Fig. $6 \mathrm{~F}$ ), while $F_{\mathrm{v}} / F_{\mathrm{m}}$ remained constant or increased under HUV-B exposure. This increase took place mostly in the last 2 bioassays without nitrate addition, suggesting some suppression of photosynthesis with $\mathrm{N}$ enrichment (e.g. Lean et al. 1982). Some of the high values reached by $\mathrm{F}_{\mathrm{v}} / \mathrm{F}_{\mathrm{m}}(\sim 0.8)$ suggest a strong contribution from green algae (Büchel \& Wilhelm 1993), consistent with the increasing relative abundance of these cells in the HUV-B bioassays. Hence, there was a clear overall effect of the UV-B treatment on $F_{\mathrm{v}} / F_{\mathrm{m}}$, and the response of $F_{\mathrm{v}} / F_{\mathrm{m}}$ to the UV-B treatment differed according to the phase of the bloom, but no significant effect of the nitrate enrichment was observed (Table 3).

\section{DISCUSSION}

\section{Phytoplankton dynamics in mesocosms at the 3 sites}

Several UV studies with natural phytoplankton communities have been performed in recent years using outdoors mesocosms (e.g. Mostajir et al. 1999, Wängberg et 
al. 1999, Bergmann et al. 2002). Although different from the natural environment, this approach has advantages mostly in terms of the more natural light environment and presence of planktonic communities resembling local conditions. Nonetheless, mesocosms are enclosed environments, and hence growth of phytoplankton mostly depends on initial nutrient levels at the time the mesocosms are filled. Accordingly, the high initial concentration of nutrients at Rimouski favored the development of a large diatom bloom. Initial nutrient and $\mathrm{chl}$ concentrations in the mesocosms were close to local field conditions in the Lower St. Lawrence Estuary in early summer (Levasseur et al. 1984, Levasseur \& Therriault 1987). The lower nutrient concentrations at the tropical site, Ubatuba, typical of these oligotrophic coastal waters (Teixeira 1979, Aidar et al. 1993), did not permit the development of a clear bloom in the mesocosms. In the southernmost site, Ushuaia, a bloom developed in the mesocosms as at Rimouski. However, chl a biomass reached lower values than at Rimouski, reflecting the lower concentration of nutrients available at Ushuaia.

As we were dealing with natural populations in the present study, microzooplankton and/or small mesozooplankton were present even though the seawater used to fill the mesocosms was pre-filtered through $500 \mu \mathrm{m}$ filters. Their influence was not assessed in the small surface-incubated bags. Pheopigments are not a reliable grazing indicator under these conditions, as high irradiance should cause their photooxidation (SooHoo \& Kiefer 1982). However, we can assume that grazers were present in similar numbers in incubation bags from specific mesocosms at the beginning of the $24 \mathrm{~h}$ bioassays. The abundance of ciliates in the Rimouski mesocosms was determined on selected dates (S. Roy unpubl.) and showed a gradual decrease in the HUV-B mesocosm, as observed by Mostajir et al. (1999). The decrease in grazing pressure in HUV-B may explain the slightly larger increases of chl $a$ and fucoxanthin in HUV-B relative to NUV-B during the third bioassay (post-bloom) at Rimouski. A similar interpretation can be offered for the second bioassay at Ubatuba, which also showed larger decreases of chl $C_{3}$ under NUV-B than HUV-B (not shown). These effects can also be seen in the evolution of chl a from the mesocosms (Fig. 2).

\section{Site-specific variations in phytoplankton sensitivity to $\mathrm{UV}-\mathrm{B}$ radiation}

No clear effect of enhanced UV-B on the rate of change of pigments could be observed overall in the stirred mesocosms at all 3 sites (Fig. 4), even though light conditions differed among them (Table 1). A more complete description of the mesocosm response is in preparation (S. Roy et al. unpubl.). This lack of effect of enhanced UV-B for pigments or cell abundance has been observed frequently in studies that use stirred mesocosms (e.g. Keller et al. 1997, Wängberg et al. 1999, Forster \& Schubert 2001), and probably reflects a moderating influence of mixing when repair is present (Helbling et al. 1992, Neale et al. 1998, 2003, Fouilland et al. 2003). The presence of at least one such repair mechanism (D1 turnover) was ascertained in our 3 sites (Bouchard et al. 2005).

In contrast, the response to enhanced UV-B in the surface incubations varied among the 3 sites. The only site where there was a clear overall detrimental effect of UV$\mathrm{B}$ on pigment changes after a $24 \mathrm{~h}$ exposure was Ushuaia. The pigment data suggest that changes in community composition took place during these incubations, with slight increases in green algae and strong decreases in chromophytes under enhanced UV-B. Unexpectedly, this led to increases in $F_{\mathrm{v}} / F_{\mathrm{m}}$ (and decreases in photoprotective pigments), probably more in response to taxonspecific changes than to photosynthetic performance alone. The relative abundance of green algae at Ushuaia could possibly result from the timing of the experiment (just after the spring bloom) and the ozone-hole period in southern South America and Antarctica (Solomon 1999). Other studies also found different taxon-specific UV-B sensitivity in this region, with phytoflagellates more sensitive than pennate diatoms during the summer (Hernando \& San Román 1999). Interestingly, this strong UV$B$ response occurred at the site that presented the smallest daily surface-fluences of the 3 sites, with lampinduced UV increases similar to those at Rimouski. While differences in community composition and in prior light acclimation probably affected this response, the low temperatures recorded at Ushuaia (the lowest of all 3 sites) are likely to have contributed to this UV-B sensitivity, notably in slowing repair processes (Bouchard et al. 2005), and hence affecting growth under enhanced UVB. Recent studies on the growth of intertidal macroalgae support the increased UV-B sensitivity as temperature decreases (Hoffman et al. 2003), although cold temperatures do not always prevent growth of phytoplankton exposed to UV-B (e.g. Antarctic diatoms, Villafañe et al. 1995).

The other temperate site, Rimouski, showed a variable response to the UV-B treatment, with detrimental effects on the net growth of pigments at surface most evident during the first 2 bioassays at Rimouski both for fucoxanthin and chl $b$ (Fig. 5). The initial response may reflect gradual acclimation to the higher average irradiance conditions of the mesocosms (only $2.3 \mathrm{~m}$ deep) compared to field conditions, where the water was taken from $\sim 5 \mathrm{~m}$ depth (indeed, $E_{\mathrm{k}}$ from $P$ - $E$ curves increased over the first few days: S. Demers unpubl.). Interestingly, even though the net growth of chl $a$ or fucoxanthin was reduced by enhanced UV-B, the values 
were still high during the bloom and post-bloom periods while the daily fluence at the surface was the highest of the 3 sites for the HUV-B treatment (Table 1). The fact that diatoms dominated the Rimouski assemblages and that a bloom was under way (with concomitant strong growth and repair rates) may explain this relative UV-B tolerance (Vernet 2000), along with increases in photoprotective pigments in the surface incubations. UV-B has been shown to stimulate the diadinoxanthin cycle in some diatoms (Goss et al. 1999). Photosynthetic performance responded differently: enhanced UV-B increased photoinhibition in all 3 bioassays at this site, but the relative increase in photoinhibition compared to that already present under ambient irradiance levels was greatest in the post-bloom period (third bioassay), perhaps reflecting less repair of UV damage when the nutrient conditions were deficient. Barbieri et al. (2002) also observed that post-bloom samples were more sensitive to UV inhibition of photosynthesis than prebloom or bloom samples. In contrast with the photosynthesis response, net growth of fucoxanthin was less affected at this time, probably because of a stronger UV-B effect on the grazers, causing an increase in net diatom growth (even though photosynthesis was affected) when grazing pressure was reduced (e.g. Bothwell et al. 1994). Thus, the Rimouski results illustrate that the phytoplankton response can vary over a short time (1 to $2 \mathrm{~d}$ ) and that the nutrient condition may affect this response (see next subsection).

The tropical site, Ubatuba, was strongly affected by ambient conditions, since there was almost no growth under all conditions tested, and photosynthetic performance was low from the start. UV-B addition thus had little further effect. This site presented the highest PAR, UV-A and UV-B irradiances of the 3 sites (Table 1), suggesting strong photoinhibition (cf. low $F_{\mathrm{v}} / F_{\mathrm{m}}$ values). High local temperatures favored high repair rates of UV damage, but this was insufficient to prevent an increase in photodamage (Bouchard et al. 2005). After 4 d, enhanced UV-B seemed to cause a stronger decrease in fucoxanthin than in zeaxanthin. A community change combined with greater photoprotection (Fig. 6C) may explain the higher $F_{\mathrm{v}} / F_{\mathrm{m}}$ values for samples from the HUV-B mesocosm during the second bioassay. Overall, the photosensitivity of Ubatuba's phytoplankton is not surprising since the assemblages were dominated by small cells which generally sustain greater DNA damage in tropical environments (e.g. Boelen et al. 2000).

\section{Nutrient influence on phytoplankton response to UV-B}

Nitrate addition to the enrichments in the surface bags significantly increased the net growth of fucoxanthin, and reduced photoinhibition only in Rimouski's third bioassay (post-bloom) and Ubatuba's first bioassay (where fucoxanthin increased only when nitrate was added), additionally reducing the POC:PON ratio in Rimouski. The fact that these significant effects were observed only for fucoxanthin suggests that the response to nitrate addition was principally by diatoms or other fucoxanthin-containing cells. During the third bioassay in Rimouski, positive growth in the surface bags (including those without nitrate addition, Fig. 5), while both chl $a$ and fucoxanthin were decreasing in the mesocosms (Fig. 4), suggests that, in addition to nitrate, silicate was probably also limiting at this site. A concurrent limitation of these nutrients for the growth of diatoms was previously observed by Levasseur \& Therriault (1987) in the Lower St. Lawrence Estuary, when both nutrients were depleted simultaneously. For all other bioassays, nutrient limitation was not sufficient to elicit a response from the nutrient enrichments, or nitrate was not the major source of nitrogen $(\mathrm{N})$. This is often observed, especially in tropical regions, where regenerated N (Metzler et al. 1997), molecular N (Paerl \& Zehr 2000) and intracellular $N$ stores are important (Lignell et al. 2003). Cells previously grown with ammonium may also not immediately respond to nitrate additions (e.g. Young \& Beardall 2003).

The response of fucoxanthin to nitrate addition was similar between the NUV-B and HUV-B treatments, both for Rimouski's third and Ubatuba's first bioassay. However, photosynthetic performance showed a greater improvement when nitrate was added to the HUV-B surface bags (compared to NUV-B), indicating that photosynthetic performance was more affected by enhanced UV-B than was net population growth. Decreased protection under enhanced UV-B conditions, e.g. through a decreased synthesis of nitrogen-rich mycosporine-like amino acids (Litchman et al. 2002) or of PSII D1 proteins (Bouchard et al. 2005), may cause increased sensitivity to UV-B under nitrogen-limited conditions. At Ubatuba, as enhanced UV-B had no effect, there were no differences between the nutrient response of the NUV-B and HUV-B treatments.

The lack of synergy between the nutrient and UV-B enhancement at Ushuaia is probably related to the large UV-B stress in the surface incubations that superseded nutrient limitation at this site. Since the experiment at Ushuaia was performed immediately after the local spring algal bloom, the phytoplankton present probably relied mostly on sources of nitrogen other than nitrate (Lignell et al. 2003).

\section{Conclusions}

In summary, our results show that responses to increased UV-B during surface incubations varied 
among the 3 study sites. Phytoplankton from the northern site, Rimouski, was relatively sensitive to increased UV-B radiation and the response of the different taxonomic groups varied with the development of the bloom. The growth of diatoms at the surface was diminished, but not prevented by enhancing UV-B. Nitrate addition significantly reduced UV-B photoinhibition, but only in the post-bloom surface incubations. Phytoplankton from the tropical site, Ubatuba, was sensitive to the high ambient-light irradiances, and enhancing UV-B had no further effect. Nitrate addition improved the photosynthetic performance and net growth of fucoxanthin, but only during the first bioassay, and there was no interaction with the UV-B response. The southernmost and coldest site, Ushuaia, showed the strongest UV-B sensitivity, but also a variable response between taxonomic groups, with fucoxanthin (mostly in small phytoflagellates) unable to grow under the enhanced UV-B conditions while green algae (chl b) grew slightly. However, in contrast with the post-bloom response at Rimouski, this response was not affected by nutrient addition (little nutrient limitation). In contrast to these UV-B effects in Rimouski and Ushuaia's surface incubations, there was no visible influence of enhanced UV-B in the stirred mesocosms, suggesting that mixing had a moderating effect in these cases. Strong UV-B effects in surface incubations (often used for estimation of rate variables) are thus not necessarily representative of effects under field (or simulated field) conditions, and will generally overestimate UV-B effects. However, the trends in UVB sensitivity observed in surface incubations may help predict changes in community structure in nature. For example, the greater tolerance of green algae relative to fucoxanthin-containing cells in Ushuaia's surface incubations matches the long-term increase in the ratio chl $b$ :chl $a$ in the mesocosms (S. Roy et al. unpubl.), even though this was not clearly recognizable from the net change of pigments in consecutive days.

Acknowledgements. This research was supported by the Inter-American Institute (IAI) for Global Change Research and by the NSERC-Collaborative Research Opportunities (S. Demers, project leader) and a grant to SR. In addition, M.L.L. was also supported by student stipends from ISMER and Québec-Océan. The authors thank J. Bouchard, K. Lacoste, F. Blouin and the other members of the UV program for logistic support. We also thank B. Klein and L. Cantoni for processing the light data and Silvia Rodríguez for the phytoplankton analyses.

\section{LITERATURE CITED}

Aidar E, Gaeta SA, Gianesella-Galvão SMF, Kutner MBB, Teixeira C (1993) Ecossistema costeiro subtropical: nutrients dissolvidos, fitoplâncton e clorofila-a e suas relações com as condições oceanográficas na região de Ubatuba, SP. Publção Esp Inst Oceanogr 10:9-43
Barbieri ES, Villafañe VE, Helbling EW (2002) Experimental assessment of UV effects on temperate marine phytoplankton when exposed to variable radiation regimes. Limnol Oceanogr 47:1648-1655

Behrenfeld MJ, Lee H II, Small LF (1994) Interactions between nutritional status and long-term responses to ultraviolet-B radiation stress in a marine diatom. Mar Biol 118: $523-530$

Bergeron M, Vincent WF (1997) Microbial food web responses to phosphorus supply and solar UV radiation in a subarctic lake. Aquat Microb Ecol 12:239-249

Bergmann T, Richardson TL, Paerl HW, Pinckney JL, Schofield O (2002) Synergy of light and nutrients on the photosynthetic efficiency of phytoplankton populations from the Neuse River Estuary, North Carolina. J Plankton Res 24:923-933

Boelen P, de Boer MK, Kraay GW, Veldhuis MJ, Buma AGJ (2000) UVBR-induced DNA damage in natural marine picoplankton assemblages in the tropical Atlantic Ocean. Mar Ecol Prog Ser 193:1-9

Bothwell ML, Sherbot DMJ, Pollock CM (1994) Ecosystems response to solar ultraviolet-B radiation: influence of trophic-level interactions. Science 265:97-100

Bouchard JN, Campbell DA, Roy S (2005) Effects of UV-B radiation on the D1 protein repair cycle of natural phytoplankton communities from three latitudes (Canada, Brazil, and Argentina). J Phycol 41:273-286

Brussaard CPD, Brookes R, Noordeloos AAM, Riegman R (1998) Recovery of nitrogen-starved cultures of the diatom Ditylum brightwelii (Bacillariophyceae) upon nitrogen resupply. J Exp Mar Biol Ecol 227:237-250

Büchel C, Wilhelm C (1993) In vivo analysis of slow chlorophyll fluorescence induction kinetics in algae: progress, problems and perspectives. Photochem Photobiol 58: $137-148$

Buma AGJ, Boelen P, Jeffrey WH (2003) UVR-induced DNA damage in aquatic organisms. In: Helbling EW, Zagarese $\mathrm{H}$ (eds) UV effects in aquatic organisms and ecosystems. Comprehensive series in photochemistry and photobiology. Vol 1. Royal Society of Chemistry, Cambridge, UK, p 291-327

Critchley C (2000) Photoinhibition. In: Raghavendra AS (ed) Photosynthesis - a comprehensive treatise. Cambridge University Press, Cambridge, p 264-271

Cullen JJ, Lesser MP (1991) Inhibition of photosynthesis by ultraviolet radiation as a function of dose and dosage rate: results for a marine diatom. Mar Biol 111:183-190

Cullen JJ, Neale PJ, Lesser MP (1992) Biological weighting function for the inhibition of phytoplankton photosynthesis by ultraviolet radiation. Science 258:646-650

Díaz SB, Nelson D, Deferrari G, Camilión C (2002) A model to extend spectral and multi-wavelength UV irradiances time series. Model development and validation. J Geophys Res 108:1-12

Díaz SB, Camilión C, Lacoste K, Escobar J, Demers S, Gianesella S, Roy S (2003) Simulation of increasing UV radiation as a consequence of ozone depletion. In: Slusser JR, Herman JR, Gao W (eds) Ultraviolet Ground- and Spacebased Measurements, Models and Effects III. Proceedings of the 48th SPIE Annual Meeting, San Diego, p 216-227

Forster RM, Schubert H (2001) The effects of ultraviolet radiation on the planktonic community of a shallow, eutrophic estuary: results of mesocosm experiments. Helgol Mar Res 55:23-34

Fouilland E, Gosselin M, Mostajir B, Levasseur M, Chanut JP, Demers S, de Mora S (2003) Effects of ultraviolet-B radiation and vertical mixing on nitrogen uptake by a natural 
planktonic community shifting from nitrate to silicic acid deficiency. Limnol Oceanogr 48:18-30

Furgal JA, Smith REH (1997) Ultraviolet radiation and photosynthesis by Georgian Bay phytoplankton of varying nutrient and photoadaptive status. Can J Fish Aquat Sci 54:1659-1667

Goss R, Mewes H, Wilhelm C (1999) Stimulation of the diadinoxanthin cycle by UV-B radiation in the diatom Phaeodactylum tricornutum. Photosynth Res 59:73-80

Grasshoff K, Ehrardt M, Kremling K (1983) Methods of seawater analysis, 2nd edn. Verlag Chemie, Weinheim

Hazzard C, Lesser MP, Kinzie RAI (1997) Effects of ultraviolet radiation on photosynthesis in the subtropical marine diatom, Chaetoceros gracilis (Bacillariophyceae). J Phycol 33:960-968

Helbling EW, Villafañe VE, Ferrario M, Holm-Hansen O (1992) Impact of natural ultraviolet radiation on rates of photosynthesis and on specific marine phytoplankton species. Mar Ecol Prog Ser 80:89-100

Helbling EW, Gao K, Gonçalves RJ, Wu H, Villafañe VE (2003) Utilization of solar UV radiation by coastal phytoplankton assemblages of SE China when exposed to fast mixing. Mar Ecol Prog Ser 259:59-66

Hernando MP, San Román NA (1999) Preliminary data on chronic effects of ultraviolet radiation on the growth of some phytoplankton species of the Beagle Channel, Argentina. Sci Mar 63:81-88

Hoffman JR, Hansen LJ, Klinger T (2003) Interactions between UV radiation and temperature limit inferences from single-factor experiments. J Phycol 39:268-272

Kana TM, Glibert PM, Goericke R, Welschmeyer NA (1988) Zeaxanthin and $\beta$-carotene in Synechococcus WH7803 respond differently to irradiance. Limnol Oceanogr 33: 1623-1627

Keller A, Hargraves P, Jeon H, Klein-Macphee G, Klos E, Oviatt C, Zhang J (1997) Ultraviolet-B radiation enhancement does not affect marine trophic levels during a winterspring bloom. Ecoscience 4:129-139

Lean DRS, Murphy TP, Pick FR (1982) Photosynthetic response of lake plankton to combined nitrogen enrichment. J Phycol 18:509-521

Lesser MP (1996) Elevated temperatures and ultraviolet radiation cause oxidative stress and inhibit photosynthesis in symbiotic dinoflagellates. Limnol Oceanogr 41:271-283

Levasseur ME, Therriault JC (1987) Phytoplankton biomass and nutrient dynamics in a tidally induced upwelling: the role of the $\mathrm{NO}_{3}: \mathrm{SiO}_{4}$ ratio. Mar Ecol Prog Ser 39:87-97

Levasseur ME, Therriault JC, Legendre L (1984) Hierarchical control of phytoplankton succession by physical factors. Mar Ecol Prog Ser 19:211-222

Lignell R, Seppälä J, Kuuppo P, Tamminen T, Andersen T, Gismervik I (2003) Beyond bulk properties: responses of coastal summer plankton communities to nutrient enrichment in the northern Baltic Sea. Limnol Oceanogr 48: 189-209

Litchman E, Neale PJ, Banaszak AT (2002) Increased sensitivity to ultraviolet radiation in nitrogen-limited dinoflagellates: photoprotection and repair. Limnol Oceanogr 47:86-94

MacIntyre HL, Kana TM, Anning T, Geider RJ (2002) Photoacclimation of photosynthesis irradiance response curves and photosynthetic pigments in microalgae and cyanobacteria. J Phycol 38:17-38

Maxwell K, Johnson GN (2000) Chlorophyll fluorescencea practical guide. J Exp Bot 51:659-668

Metzler PM, Glibert PM, Gaeta SA, Ludlam JM (1997) New and regenerated production in the South Atlantic off Brazil. Deep-Sea Res I 44:363-384
Mostajir B, Demers S, de Mora S, Belzile C and 9 others (1999) Experimental test of the effect of ultraviolet-B radiation in a planktonic community. Limnol Oceanogr 44:586-596

Neale PJ, Kieber DJ (2000) Assessing biological and chemical effects of UV in the marine environment: spectral weighting functions. In: Hester RE, Harrison RM (eds) Causes and environmental applications of increased UV-B radiation Royal Society of Chemistry, Cambridge, p 61-83

Neale PJ, Davis RF, Cullen JJ (1998) Interactive effects of ozone depletion and vertical mixing on photosynthesis of Antarctic phytoplankton. Nature 392:585-589

Neale PJ, Helbling EW, Zagarese HE (2003) Modulation of UVR exposure and effects by vertical mixing and advection. In: Helbling EW, Zagarese $\mathrm{H}$ (eds) UV effects in aquatic organisms and ecosystems. Comprehensive series in photochemistry and photobiology. Vol 1. Royal Society of Chemistry, Cambridge, p 107-134

Paerl HW, Zehr JP (2000) Marine nitrogen fixation. In: Kirchman DL (ed) Microbial ecology of the oceans. Wiley-Liss, New York, p 387-426

Riley GA (1957) Phytoplankton of the north central Sargasso Sea. Limnol Oceanogr 2:252-270

Roos JC, Vincent WF (1998) Temperature dependence of UV radiation effects on antarctic cyanobacteria. J Phycol 34: 118-125

Roy S, Chanut JP, Gosselin M, Sime-Ngando T (1996) Characterization of phytoplankton communities in the lower St. Lawrence Estuary using HPLC-detected pigments and cell microscopy. Mar Ecol Prog Ser 142:55-73

Scheiner SM, Gurevitch J (1993) Design and analysis of ecological experiments. Chapman \& Hall, London

Schreiber U, Neubauer C, Schliwa U (1993) PAM fluorometer based on medium-frequency pulsed Xe-flash measuring light: a highly sensitive new tool in basic and applied photosynthesis research. Photosynth Res 36:65-72

Sobrino C, Neale PJ, Lubián (2005) Interaction of UV radiation and inorganic carbon supply in the inhibition of photosynthesis: spectral and temporal responses of two marine picoplankters. Photochem Photobiol 81:384-393

Solomon S (1999) Stratospheric ozone depletion: a review of concepts and history. Rev Geophys 37:275-316

SooHoo JB, Kiefer DA (1982) Vertical distribution of phaeopigments. II. Rates of production and kinetics of photooxidation. Deep-Sea Res 29:1553-1563

Strickland JDH, Parsons TR (1972) A practical handbook of seawater analysis, 2nd edn (revised). Bull Fish Res Board Can 167:1-310

Tarasick DW, Fioletov VE, Wardle DI, Kerr JB, McArthur LJB, McLinden CA (2003) Climatology and trends of surface UV radiation. Atmos-Ocean 41:121-138

Teixeira C (1979) Primary production and some ecological considerations from Ubatuba region (Lat. 23 degree 30 'S Long. 45 degree 06'W), Brazil. Bol Inst Oceanogr 28:23-28

Veen A, Reuvers M, Ronçak P (1997) Effects of acute and chronic UV-B exposure on a green alga: a continuous culture study using a computer-controlled dynamic light regime. Plant Ecol 128:29-40

Vernet M (2000) Effects of UV radiation on the physiology and ecology of marine phytoplankton. In: de Mora S, Demers $\mathrm{S}$, Vernet $\mathrm{M}$ (eds) The effects of UV radiation in the marine environment. Cambridge University Press, Cambridge, $p$ $237-278$

Villafañe VE, Helbling EW, Holm-Hansen O, Chalker BE (1995) Acclimatization of Antarctic natural phytoplankton assemblages when exposed to solar ultraviolet radiation. J Plankton Res 17:2295-2306

Villafañe VE, Barbieri ES, Helbling EW (2004) Annual pat- 
terns of ultraviolet radiation effects on temperate marine phytoplankton off Patagonia, Argentina. J Plankton Res 26:167-174

Vincent WF, Neale PJ (2000) Mechanisms of UV damage to aquatic organisms. In: de Mora S, Demers S, Vernet M (eds) The effects of UV radiation in the marine environment. Cambridge University Press, Cambridge, p 149-176

Vincent WF, Roy S (1993) Solar ultraviolet-B radiation and aquatic primary production: damage, protection, and recovery. Environ Rev 1:1-12

Wängberg SÅ, Garde K, Gustavson K, Selmer JS (1999) Effects of UVB radiation on marine phytoplankton communities. J Plankton Res 21:147-166

Wright SW, Jeffrey SW, Mantoura RFC, Llewellyn CA, Bjørnland T, Repeta D, Welschmeyer N (1991) Improved HPLC method for the analysis of chlorophylls and carotenoids

Editorial responsibility: Otto Kinne (Editor-in-Chief), Oldendorf/Luhe, Germany from marine phytoplankton. Mar Ecol Prog Ser 77: 183-196

Wulff A, Wängberg SA, Sundbäck K, Nilsson C, Underwood GJC (2000) Effects of UVB radiation on a marine microphytobenthic community growing on a sand-substratum under different nutrient conditions. Limnol Oceanogr 45: 1144-1152

Young EB, Beardall J (2003) Rapid ammonium- and nitrateinduced perturbations to chl a fluorescence in nitrogenstressed Dunaliella tertiolecta (Chlorophyta). J Phycol 39: 332-342

Zapata M, Rodríguez F, Garrido JL (2000) Separation of chlorophylls and caratenoids from marine phytoplankton: a new HPLC method using a reversed phase $\mathrm{C}_{8}$ column and pyridine-containing mobile phases. Mar Ecol Prog Ser 195:29-45

Submitted: November 15, 2004; Accepted: September 19, 2005 Proofs received from author(s): March 30, 2006 